\section{Research Square}

Preprints are preliminary reports that have not undergone peer review

They should not be considered conclusive, used to inform clinical practice, or referenced by the media as validated information.

\title{
Evaluation of Microbial Diversity, Community Composition and Function in Mixed Cropping Systems Using Three Legume Species Under the Application of Biochar or Chemical Fertiliser
}

Akari Kimura ( $\square$ akari-2245@eis.hokudai.ac.jp)

Hokkaido University Graduate School of Chemical Sciences and Engineering: Hokkaido Daigaku Daigakuin Sogo Kagakuin https://orcid.org/0000-0002-7450-133X

\section{Yoshitaka Uchida}

Hokkaido University Graduate School of Chemical Sciences and Engineering: Hokkaido Daigaku Daigakuin Sogo Kagakuin https://orcid.org/0000-0003-4354-7842

\section{Research Article}

Keywords: Mixed cropping, Microbial diversity, Biochar, Nitrogen cycling

Posted Date: July 16th, 2021

DOI: https://doi.org/10.21203/rs.3.rs-695338/v1

License: @ (i) This work is licensed under a Creative Commons Attribution 4.0 International License. Read Full License 


\section{Abstract}

Mixed cropping systems involve utilising multiple crop species on the field and diversifying aboveground plants. However, several contradicting results have been reported regarding their effects on soil microbial diversity. Therefore, to evaluate the effects of different leguminous species used in mixed cropping systems and the types of fertiliser on the diversity of soil microbes, a pot study was performed under maize/legume mixed cropping systems with one of three legumes, including cowpea [Vigna unguiculata (L.) Walp.], velvet bean [Mucuna pruriens (L.) DC.] and common bean (Phaseolus vulgaris L.), and one of three types of fertiliser treatments, namely chemical fertiliser (CF), carbonised chicken manure (CM) or the lack of fertiliser (Ctr). 16S rRNA analyses were conducted using the soils sampled from each pot for soil bacterial diversity assessment, and Tax4Fun2 was used for bacterial functional prediction analysis. A decrease in microbial diversity after $\mathrm{CM}$ application was observed in the soil with velvet bean + maize (MM) compared to the Ctr treatment, whereas an increase in microbial diversity was observed in the soil with common bean + maize (PM) in the same condition. With CM application, the abundance of treatment-unique bacteria increased with PM treatment, whereas their decrease was observed with MM treatment. In contrast, the abundance of dominant microbes, including Thaumarchaeota, Chloroflexi, Planctomycetes and Verrucomicrobia, was significantly lower in PM but higher in MM after $\mathrm{CM}$ application. Functional prediction analysis indicated that the dominant bacteria were involved in $\mathrm{CM}$ decomposition processes and nitrification in MM treatment. Legume species-dependent factors, including nutrient absorption and root exudate composition, might be important concerning soil bacterial diversities.

\section{Introduction}

The expansion of agricultural lands has been the primary cause of biodiversity loss in terrestrial ecosystems (Bossio et al., 2005; Kehoe et al., 2017; Zabel et al., 2019). Particularly, modern agricultural practices, including monoculture cropping systems, the intensive use of inorganic fertilisers and pesticides, lead to soil degradation and loss of genetic diversity (Díaz et al., 2006; Rohr et al., 2019). Therefore, establishing efficient agricultural crop production systems compatible with biodiversity conservation is a global challenge for future food security.

Among different scales of biodiversity, the diversity of soil microorganisms is especially important for the stability of agricultural ecosystems. They can be considered the main drivers of biogeochemical reactions beneficial for soil health and crop productivity (Chaparro et al., 2012; Singh, 2015). For example, their involvement is notable in biogeochemical processes essential for plant health and growth, including nutrient absorption, immune function, pathogen prevention and stress tolerance (Loreau et al., 2001; Nannipieri et al., 2003). Thus, agricultural management systems to maintain or increase soil microbial diversity must be established.

Among various agricultural practices that can potentially diversify soil microbes, the use of mixed cropping systems is receiving heightened attention. Legume-based intercropping systems have been reported to enhance soil microbial diversity and bacterial functions, including the mineralisation of available phosphorus (P) and nitrogen (N) (Gao et al., 2010; Li et al., 2013; Lian et al., 2019; Lingling Yu et al., 2020). Moreover, mixed cropping systems with field pea varieties have been demonstrated by Horner et al. (2019) to build stronger and larger cooccurrence networks in rhizosphere bacterial communities. These studies have suggested that crop diversification, including mixed cropping systems, improves soil microbial diversity and nutrient availability in agricultural soil. However, besides successful cases, no significant difference in bacterial diversity or functional availability in multiple cropping systems has been observed in previous studies (Granzow et al., 2017; Li et al., 2010; Zhang et al., 2010). These conflicting results indicate more complex mechanisms of microbial diversification in mixtures of plant species because soil microbial communities in mixed cropping systems become complex, reflecting synergistic and antagonistic interactions while plants grow in mixed cultures (Li et al., 2010). These interactions are influenced not only by mixed crop species but also by nutrient availability in the soil. However, it is still unclear how plant species-specific interaction in mixed cropping systems changes soil microbial community under varied nutrient availabilities, influenced by agricultural management factors, such as inorganic or organic fertiliser application. Therefore, information about the response of microbial diversity to the use of different fertilisers should be accumulated using variable legume species.

Among variable fertilisation treatments, biochar, an organic fertiliser, has been reported by many previous studies to have positive effects on soil microbial diversity and functionality in mixed cropping systems (Chen et al., 2016; Francioli et al., 2016; Gong et al., 
2009; Gul et al., 2015; He et al., 2008). For example, the combined use of biochar composed of plant residues and legume-based intercropping systems could enhance the soil microbial functionality important for nutrient absorption by plants, such as $\mathrm{N}$-fixation and P-solubilisation in the rhizosphere (Duchene et al., 2017; Liao et al., 2019; Liu et al., 2017). Also, biochar application increases available $\mathrm{N}$ to plant because biochar increases soil pH and stimulates the access of ammonia-oxidising bacteria to $\mathrm{NH}_{4}{ }^{+}$and reduces gaseous $\mathrm{N}$ loss from soil by reducing the denitrification potential (Lu Yu et al., 2020). Furthermore, in mixed cropping systems, $\mathrm{N}$ mineralisation of biochar, the process of transformation of organic $\mathrm{N}$ to mineral $\mathrm{N}$ through soil microorganism activities, can be different by legume species because individual plant species can stimulate different microorganisms involved in the $\mathrm{N}$ cycle through their root activities, such as root exudation and fine root turnover (Acosta-Mercado and Lynn, 2006; Cardarelli et al., 2020; Marschner et al., 2004; Sanchez-Contreras et al., 2007). However, still few studies have examined the effects of biochar on bacterial functionality and diversity among variable legume species.

Studies focusing on 'rare' microbial taxa are notably important to evaluate the mechanisms of soil microbial diversification and functionality. Recent studies have suggested that rare microbial taxa ( 1\%-3\% within the relative abundance), appearing only under certain fertilisation management conditions, have a critical role in soil multifunctionality in agricultural soils (Chen et al., 2020; Hol et al., 2010; Kurm et al., 2017). This can be due to the overproportional roles played by these rare taxa in soil nutrient cycles, including $\mathrm{N}$ and $\mathrm{C}$ cycles and the degradation of complex chemicals (Jousset et al., 2017). Therefore, the ecology of rare microbes should be considered together to examine bacterial functional variability with the microbial diversification process.

This study aimed to elucidate plant species-specific effects of cereal/legume mixed cropping on soil microbial community structures, focusing on the interaction among legume species and fertiliser types. It was hypothesised that the combination of legume species and fertiliser types is important for bacterial diversity and community structure and the abundance of rare bacterial species. Further, the growth of a rare microbial community in diversified treatment was assumed to have an important role in the degradation process of complex chemicals, especially focusing on organic $\mathrm{N}$ degradation. Thus, a greenhouse experiment of legume-maize mixed cropping was performed using three legume varieties and chemical or biochar [carbonised chicken manure (CM)] to measure bacterial diversity and community structure and their functionality based on 16S rRNA analysis.

\section{Materials And Methods}

\subsection{Soil sampling}

The soil used in this experiment was sampled from abandoned land for 30 years at the university farm located at the Field Science Centre for Northern Biosphere, Hokkaido University, Japan $\left(43^{\circ} 04 \hat{c} \mathrm{~N}, 141^{\circ} 20 \mathrm{c} \mathrm{E}\right)$. The properties of the soil are given in Table 1. The soil type was clay loam with $44.6 \%$ sand, $21.5 \%$ silt and $33.9 \%$ clay.

\subsection{Experimental design}

A pot experiment was performed in a greenhouse at the Graduate School of Hokkaido University. The sampled soil was air-dried and sieved with $2 \mathrm{~mm}$ mesh and subsequently filled into Wagner pots (surface area = 1/5000 a). Each pot contained $1.8 \mathrm{~kg}$ airdried soil. The experimental design was completely randomised, included three fertiliser treatments $\times$ four mixed cropping treatments, and conducted in trireplicates. The pots received one of the three types of fertiliser treatments, namely control ('Ctr'), chemical fertiliser containing $\mathrm{P}$ and $\mathrm{K}$ ('CF') or biochar made from CM (50 g pot ${ }^{-1}$ carbonised $\mathrm{CM}$; 'CM'). The application rate for $\mathrm{CF}$ was $30 \mathrm{~kg} \mathrm{P} \mathrm{ha}^{-1}$ and $50 \mathrm{~kg} \mathrm{~K} \mathrm{ha}^{-1}$. The soil and the $\mathrm{CM}$ chemical property are described in Table 1.

Each pot then received one of the four types of plant treatment: (1) single maize (Zea mays L.; SM), (2) mixture of cowpea [Vigna unguiculata (L.) Walp.] and maize (VM), (3) mixture of velvet bean [Mucuna pruriens (L.) DC.] and maize (MM) and (4) mixture of common bean (Phaseolus vulgaris L.) and maize (PM). Three replications were included in each treatment. During these treatments, maize and three legume seeds, including cowpea, velvet bean and common bean, were sprouted for 2 weeks in small pots filled with vermiculite before transplantation to Wagner pots. During the experiment, the temperature was maintained at $25^{\circ} \mathrm{C}$ to $30^{\circ} \mathrm{C}$, and the plants were grown for 50 days after transplantation. 


\subsection{Chemical property analysis}

After plant growth soil was sampled from each pot, soils were sampled and measured for $\mathrm{pH}$ and extractable $\mathrm{NH}_{4}{ }^{+}$and $\mathrm{NO}_{3}{ }^{-}$ concentrations 50 days after transplantation. For soil pH, $6 \mathrm{~g}$ soil was shaken for 30 min with $30 \mathrm{~mL}$ Milli-Q water, and pH was subsequently measured by a pH sensor (AS800; ASONE Co., Japan). For extractable $\mathrm{NH}_{4}{ }^{+}$and $\mathrm{NO}_{3}{ }^{-}$, the samples were extracted with a $\mathrm{KCl}$ solution $\left(2 \mathrm{~mol} \mathrm{~L}^{-1}\right)$, followed by colorimetric analysis using a flow injection analyser system (ACLA-700; Aqualab Co., Ltd., Japan). A two-way analysis of variance (ANOVA) was then performed to investigate the interaction between environmental factors and experimental treatments (Table 2).

\subsection{DNA extraction and $16 \mathrm{~S}$ rRNA sequencing}

Using the same sampled soils, DNA was extracted with NucleoSpin® Soil (Takara Bio, Inc., Japan) according to the manufacturer's instructions. The extracted DNA was subsequently amplified by polymerase chain reaction (PCR) targeting the V4 region of $16 \mathrm{~S}$ rRNA (amplicon size 250 bp; forward primer 515F: 5'-GTGCCAGCMGCCGCGGTAA-3' and reverse primer 806R: 5'GGACTACHVGGGTWTCTAAT-3'). To perform PCR, $10 \mu \mathrm{L}$ AmpliTaq Gold® 360 Master Mix (Applied Biosystems, Foster City, CA, USA), $0.4 \mu \mathrm{L}$ of the forward primer, $0.4 \mu \mathrm{L}$ of the reverse primer, $7.2 \mu \mathrm{L}$ nuclease-free water and $1 \mu \mathrm{L}$ DNA extract were mixed. The first PCR cycle was set to $95^{\circ} \mathrm{C}$ for $10 \mathrm{~min}$ and then 20 cycles at $95^{\circ} \mathrm{C}$ for $30 \mathrm{~s}, 57^{\circ} \mathrm{C}$ for $30 \mathrm{~s}$ and $72^{\circ} \mathrm{C}$ for $1 \mathrm{~min}$, followed by $72^{\circ} \mathrm{C}$ for $7 \mathrm{~min}$. The PCR products were subsequently purified with Agencourt AMPure XP (Beckman Coulter) according to the given protocol. Then, the purified products were quantified with the QuantiFluor® ONE dsDNA System by a QuantusÔ Fluorometer E6150 (Promega, Madison, WI, USA).

Another PCR was performed with the utilisation of amplicon-obtained products to make them lon Torrent sequence sample-specific. To achieve this, the 515F forward primer with the lon Xpress Barcode Adapters Kit sequence and the 806R reverse primer attached to the Ion Xpress sequence of the Ion P1 adaptor were used (Thermo Fisher Scientific K.K.). The first PCR products were diluted to $2000 \mathrm{ng} \mathrm{mL}^{-1}$, and $1 \mu \mathrm{L}$ of each product was subsequently mixed with $10 \mu \mathrm{L}$ AmpliTaq Gold $\circledast 360$ Master Mix, $0.4 \mu \mathrm{L}$ of the forward primer, $0.4 \mu \mathrm{L}$ of the reverse primer and $7.2 \mu \mathrm{L}$ nuclease-free water. The second PCR cycle was set to $95^{\circ} \mathrm{C}$ for $10 \mathrm{~min}$ and then 5 cycles at $95^{\circ} \mathrm{C}$ for $30 \mathrm{~s}, 57^{\circ} \mathrm{C}$ for $30 \mathrm{~s}$ and $72^{\circ} \mathrm{C}$ for $1 \mathrm{~min}$, followed by $72^{\circ} \mathrm{C}$ for $7 \mathrm{~min}$. The second PCR products were purified in accordance with the same method outlined above. The final length and concentration of the amplicons were confirmed using a Bioanalyzer DNA 1000 Kit (Agilent Technologies, USA). The library was subsequently diluted to 50 pM and loaded into the lon 318 chip using lon Chef Instruments with an Ion PGM Hi-Q Chef Solutions. The samples were sequenced on an lon PGM Sequencer with Ion PGM Hi-Q View Sequence Solutions (Ion Torrent Life Technologies, USA). Sequence data were deposited in the Sequence Read Archive of the National Center for Biotechnology Information (NCBI) under accession number PRJNA743765.

\subsection{Sequence processing}

The barcoded 16S rRNA gene sequences were denoised, quality-filtered and assessed using the DADA2 algorithm implemented in Quantitative Insights Into Microbial Ecology (QIIME2) and with its workflow (Bolyen et al., 2019). Rarefaction was performed with minimal reads among all samples, and sequence data were subsampled to 41,095 sequences per sample. The $\mathrm{R}$ package Vegan (version 2.5.6) was used to access sample depth and generate the a-rarefaction curve plot (Fig. S1). The rarefaction curve was then evaluated using the interval of a step sample size of 1000 .

\subsection{Measurement of bacterial abundance}

To measure bacterial abundance, quantitative PCR (qPCR) was performed using the extracted DNA, diluted 50 times with nucleasefree water. The 515F/806R primer pairs described above were used to amplify the V4 region of the 16S rRNA. For the standard curve, the PCR products from the DNA extracted from the Ctr pots were used, which were purified with AMPure XP and further diluted to five stages of different concentrations. The samples were prepared with 10.4 $\mu \mathrm{L} \mathrm{KAPA} \mathrm{SYBR} \mathrm{Fast} \mathrm{qPCR} \mathrm{kit} \mathrm{(Kapa}$ Biosystems, USA), $0.08 \mu \mathrm{L}$ of the forward primer, $0.08 \mu \mathrm{L}$ of the reverse primer and $2 \mu \mathrm{L}$ diluted DNA extract. Nuclease-free water was added to achieve the final volume of 20 LL. CFX96 TouchÔ Real (Bio-Rad Laboratories, Inc., USA) was used, and the cycling

Page $4 / 18$ 
condition was set to $95^{\circ} \mathrm{C}$ for $30 \mathrm{~s}$ and then 35 cycles at $95^{\circ} \mathrm{C}$ for $30 \mathrm{~s}, 58^{\circ} \mathrm{C}$ for $30 \mathrm{~s}$ and $72^{\circ} \mathrm{C}$ for 1 min, followed by $95^{\circ} \mathrm{C}$ for 1 min and subsequently $55^{\circ} \mathrm{C}$ to $95^{\circ} \mathrm{C}$ by $1^{\circ} \mathrm{C}$ increment for $10 \mathrm{~s}$. Ct values (threshold cycle) were calculated after quantifying the amplification results using qpcR $\mathrm{R}$ package version 1.4.1.

\subsection{Statistical analysis}

To quantify the diversity of soil microbial communities, the Shannon index (Shannon, 1948) and the Simpson index (Simpson, 1949), an estimation of community a-diversity, were calculated. For each diversity index, two-way ANOVA was performed using fertiliser treatments and plant species as factors with the emmeans R package version 1.4.7 (Lenth et al., 2020). Multiple comparisons were subsequently performed using the Tukey-Kramer method. Also, permutational ANOVA (PERMANOVA; permutation $=9999)$ was conducted, and significant phyla $(p<0.001)$ were subsequently identified for the interactions between fertiliser treatments and plant types using two-way ANOVA.

The numbers of operational taxonomy units (OTUs) for each plant treatment within the same fertiliser treatment were illustrated using Venn diagrams. VennDiagram R package version 1.6.20 was applied using the cooccurred OTUs among three replications for each treatment. OTUs that specifically appeared by plants species within each fertilisation were defined as unique OTUs and classified to the phylum. The relative abundance of unique OTUs within the total abundance was plotted for PM and MM treatments that were significantly different in diversity indices within plant species.

Functional profiling of the prokaryotic community was conducted with the Tax4Fun2 R package (Wemheuer et al., 2020). The rarefied OTU table was used for Tax4Fun2 searches, and metagenome functional profiles were predicted to generate a table of Kyoto Encyclopedia of Gene and Genomes orthologs (Kanehisa and Goto, 2000). To evaluate biogeochemical reactions, 36 genecoding enzymes related to the organic N degradation and N metabolism pathway were selected (Table S1; Harter et al., 2014; He et al., 2021; Sulieman and Tran, 2014; J. Wang et al., 2020) and visualised with 'ComplexHeatmap' R package.

\section{Results}

\subsection{Diversity indices and abundance of bacterial communities}

The interaction effects between plant species and fertilisation were shown by soil microbial diversity indices. Within PM treatment, a significantly lower Simpson's diversity indicator was observed with no fertilisation (Ctr) compared to CM treatment (Fig. 1). In contrast, a relatively lower diversity was shown by MM treatment with CM application compared to Ctr treatment.

Bacterial absolute abundance, based on qPCR analyses, showed a significant effect of plant treatments when averaged across fertiliser types (Table S2). The bacterial abundance of SM and VM treatments was significantly different. However, there was no correlation between bacterial absolute abundance and diversity indicators.

The analysis of the soil 16S rRNA gene sequence provided 738 to 1196 OTUs per sample. Venn diagrams showed that soils under Ctr, CF and CM treatments had 297, 293 and 283 core OTUs (the overlapped area across plant treatments), respectively (Fig. 2) and increasing numbers of unique OTUs with increasing diversity indices, for example, unique OTU numbers increased from 28 to 84 for $\mathrm{PM}$ compared to $\mathrm{Ctr}$ and $\mathrm{CM}$, whereas it decreased from 52 to 35 in MM. The relative abundance of these unique bacteria within the whole bacterial abundance increased from 1.9\% (Ctr) to 5.2\% (CM) in PM treatment but decreased from 4.3\% (Ctr) to 1.9\% (CM) in MM treatment (Fig. 3). The abundance of Acidobacteria and Verrucomicrobia was suggested by the community structures of these unique bacterial taxa to dominate within unique microbial communities and was correlated to the increase of unique OTU numbers during comparison of different treatments. In contrast, the abundance of Gemmatimonadates, Chloroflexi and Planctomycetes was not correlated to the increase in unique OTU numbers, although they were considered to be the dominant phyla within unique OTUs.

\subsection{Environmental factors and dominant OTU composition}

The relative abundance of Thaumarchaeota, Armatimonadetes, Chloroflexi, Planctomycetes, Verrucomicrobia and Proteobacteria contributed to the changes in community structures, and their abundance was influenced by the interactions between plant species 
and fertiliser treatments (Table 3; Fig. S2). Within CM treatment, Thaumarchaeota, Chloroflexi, Planctomycetes and Verrucomicrobia were significantly higher in MM treatment than PM treatment $(p<0.05$; Table 4$)$.

The significant increase in soil pH in $\mathrm{CM}$ treatment was due to the content of salt-based ions, such as potassium, sodium and calcium, which can reduce the exchangeable hydrogen ions in the soil (Table 2). Also, $\mathrm{CM}$ application significantly increased $\mathrm{NO}_{3}{ }^{-}-$ $\mathrm{N}$ concentration $(p<0.001)$, but $\mathrm{NH}_{4}{ }^{+}-\mathrm{N}$ concentration had no significant difference $(p=0.90)$.

\subsection{Functional prediction by Tax4Fun2}

Two-way ANOVA analysis indicated that gene abundance coding ammonium oxidation, carbamate kinase, glutamate dehydrogenase, nitrate reductase, nitrite oxidoreductase and nitrite reductase (NO-forming) was significantly influenced by the interaction effects of plant type and fertiliser (Table S1). In Ctr treatment, gene abundance coding ammonium oxidation and nitrite reductase (NO-forming) were higher in mixtures of legume and maize (Fig. 4). In contrast, in CF, there was no difference in gene abundance coding ammonium oxidation and nitrite reductase (NO-forming) between single and mixed cropping treatments. CM treatment most altered gene abundance among other fertilisation treatments. Especially, with CM application, MM treatment showed the highest abundance in glutamate dehydrogenase, carbamate kinase, ammonium oxidation and nitrate reductase.

\section{Discussion}

\subsection{Characteristics of unique bacteria}

The diversity index and unique bacterial abundance in PM were significantly higher in CM treatment, whereas CM negatively affected the diversity and unique bacterial abundance in MM (Fig. 1 and 2). There was no universal effect of mixed legume species and fertiliser types on soil bacterial diversities. There was also no consistent statement about microbial diversity in multiple cropping systems using cereals and legumes in previous studies. For example, Fu et al. (2019) and Kihara et al. (2012) found that an intercropping system with maize and soybean increased microbial diversity, whereas Yu et al. (2019) showed that there was no significant effect of the intercropping system on microbial diversity. This study demonstrated both plant species and fertiliser types were related to the mechanisms behind the diversification of soil microbes. Especially, this study highlighted the importance of the use of CM, compared to CF, in association with the diversification of soil microbes. Liao et al. (2019) indicated that different microbial communities could utilise plant exudates depending on the presence or absence of biochar in the intercropping system using the ${ }^{13} \mathrm{C}$ tracer method. Biochar application changes the influence of plant exudates on microbial community and diversity in the intercropping system due to the absorption of root exudates on its surface area or its porosity characteristics.

Also, plant species were identified as an important factor controlling the presence of unique bacteria when CM was applied as different plants have different abilities to recruit specific bacterial communities (Zhang et al., 2019). Regarding unique OTUs, the abundance of Acidobacteria and Verrucomicrobia was positively correlated with the percentage of unique OTUs and the diversity indices (Fig. 3). In rhizosphere soils, these bacteria often dominate the present bacterial communities due to their relatively higher metabolic potential (Barns et al., 2007; Bünger et al., 2020; Lee et al., 2008). Whole-genome sequence analyses of Acidobacteria strains revealed that they are involved in carbohydrate metabolism to utilise plant root exudates (de Chaves et al., 2019; Kielak et al., 2016; Nielsen et al., 2014). Also, Verrucomicrobia were reported to hold diverse communities in the rhizosphere (Bünger et al., 2020), and their role in polysaccharide degradation processes was identified (Dunfield et al., 2007; He et al., 2017; Pold et al., 2018). It is possible that the amount and quality of root exudates affected soil microbiomes differently when PM and MM were compared, as soil microbes showed a preference in association with the exudate (substrates) supplied from the plant roots (Duchene et al., 2017; Zhalnina et al., 2018). This study indicated that biochar application on mixed cropping systems diversifies the soil bacterial community in a short period only with certain legumes, although further studies are needed to investigate the chemical composition of root exudates and their effect on unique bacterial community and their interaction with the use of biochar.

\subsection{Enzyme activity related to the $\mathbf{N}$ cycle}


Functional prediction analysis with Tax4Fun2 indicated that without fertiliser (Ctr) the presence of legume facilitated nitrification and denitrification with higher $\mathrm{NO}_{3}{ }^{-}$concentrations in the soil (Fig. 4; Table 2), as shown by higher gene abundance coding ammonia oxidation and nitrite reductase (NO-forming). In contrast, mixed cropping systems in CF treatment did not show positive effects on ammonia oxidation and nitrite reductase (NO-forming) activities with low $\mathrm{NO}_{3}{ }^{-}$concentrations in the soil. In the early stage of mixed cropping systems, $\mathrm{P}$ is often a limitation of plant growth (Ghosh et al., 2009), whereas $\mathrm{N}$ becomes a limitation during sufficient $P$ supply (Isaac et al., 2012). Although fertilisers containing $P$ and $K$ facilitated $N$-fixation by legume (Cadisch et al., 1993; Collins et al., 1986; Sangakkara et al., 1996), and this study showed more nodulation in MM and PM with CF treatment (Table S3), the low gene abundance in the mixed treatment indicated that $\mathrm{N}$ deficiency occurred between maize and legume through $\mathrm{CF}$ application. Moreover, compared to Ctr and CF, CM treatment dynamically affected $\mathrm{N}$ cycling in each cropping system because of their organic $\mathrm{N}$ contents. In MM with CM treatment, the abundance of ammonia oxidation and nitrite reductase (NO-forming) was higher. The abundance of carbamate kinase and glutamate dehydrogenase, which mediate amino acid metabolism, was higher than other plant treatments. A higher abundance of those genes might be related to the fast decomposition of organic $\mathrm{N}$ in $\mathrm{CM}$ and the supply of more $\mathrm{N}$ to plants and the greater growth of coplanted maize in MM (Table S3). In contrast, the lower abundance of those enzymes in PM might be related to the slower growth of maize. In previous research, intercropped maize (Z. mays $L$.) with wheat (Triticum aestivum L.) or faba bean (Vicia faba L.) showed maize growth suppression in the initial cultivation period to avoid nutritional competition with neighbour species (Li et al., 2011). In this study, a similar pattern appeared in PM, whereas little suppression was observed in MM. It is also consistent with a previous study with intercropping using velvet bean, which showed fewer maize growth suppressions or even better growth than monocropping (Akobundu et al., 2000; Correia et al., 2014). These studies on weed reduction by cover crop effects of velvet bean were significant with maize growth, but they lacked focus on the mechanism to avoid $\mathrm{N}$ competition between velvet bean and maize. Thus, this study provided a better understanding of how velvet bean maintains greater growth of maize than other legumes in terms of the bacterial community driving $\mathrm{N}$ cycling.

While comparing community structures at the phylum level within CM-applied soils, the abundance of Thaumarchaeota, Chloroflexi, Planctomycetes and Verrucomicrobia was significantly higher in MM compared to PM (Table 4). Especially, Thaumarchaeota, an archaea ubiquitously present in a wide variety of ecosystems, would contribute to the increase of ammonium-oxidising function (Brochier-Armanet et al., 2012; Cardarelli et al., 2020; Pester et al., 2011; Spang et al., 2010). Also, members of Planctomycetes can perform anaerobic oxidation of ammonium to dinitrogen via the annamox pathway, which might be related to higher denitrification functionality in MM (Andrei et al., 2019; Fuerst and Sagulenko, 2011). Moreover, Verrucomicrobia and Chroloflexi are often associated with carbohydrate and amino acid degradation (Bayer et al., 2018; Herlemann et al., 2013; Martinez-Garcia et al., 2012; Yamada et al., 2005). The results of this study indicated that MM with CM enhanced dominant bacterial growth and facilitated organic $\mathrm{N}$ decomposition and nitrification, producing plant deliverable N. However, Tax4Fun2 is a prediction of bacterial functionality from $16 \mathrm{~S}$ amplicon sequences, so further efforts are required to determine bacterial functional DNA sequencing in relation to the nutrient cycle.

\section{Conclusion}

Mixed cropping systems diversify soil bacterial communities only under a specific combination of legume species and fertilisers. Soil bacterial diversity was increased when biochar was used for the common bean-based mixed cropping system with an increase in the number of unique OTUs (treatment-specific OTUs). Especially, plant root associated bacteria such as Verrucomicrobia and Actinobacteria were increasing in diversified treatment.

With biochar application, bacterial functionalities, such as ammonia oxidation and denitrification, were higher in the velvet beanbased mixed cropping system with a low diversified bacterial community. Some dominant bacterial phyla, such as Thaumarchaeota, Planctomycetes, Verrucomicrobia and Chloroflexi, contributed higher enzyme abundance related to organic $\mathrm{N}$ decomposition in the mixed cropping system with velvet bean and biochar.

Further efforts are needed to confirm the effects of plant root exudates on soil microbial community and diversity in association with biochar application. Also, as a limitation of the pot study, only bacterial diversity and functionality were evaluated early on cultivation. Therefore, field research to evaluate the long-term effects of mixed cropping systems on the bacterial diversification process and functionality associated with the variability of legume species and fertiliser types is required.

Page $7 / 18$ 


\section{Declarations \\ Funding}

This work was supported by JSPS KAKENHI grant numbers 18 KK0183 and $18 \mathrm{H} 02310$.

\section{Conflicts of interest/Competing interests}

To the best of our knowledge, the named authors have no conflict of interest, financial or otherwise.

\section{Availability of data and material}

Sequence data were deposited in the Sequence Read Archive of the National Center for Biotechnology Information (NCBI) under accession number PRJNA743765 (https://www.ncbi.nlm.nih.gov/bioproject/PRJNA743765). The other datasets during and/or analysed during the current study available from the corresponding author on reasonable request.

\section{Code availability}

The code used in this study are available from the corresponding author on reasonable request.

\section{Ethics approval}

Not applicable

\section{Consent to participate}

Not applicable

\section{Consent for publication}

Not applicable

\section{References}

1. Acosta-Mercado D, Lynn DH (2006) Contrasting soil ciliate species richness and abundance between two tropical plant species: a test of the plant effect. Microb Ecol 51:453-459. https://doi.org/10.1007/s00248-006-9067-3

2. Akobundu IO, Udensi UE, Chikoye D (2000) Velvetbean (Mucuna spp.) suppresses speargrass (Imperata cylindrica (L.) Raeuschel) and increases maize yield. International Journal of Pest Management 46:103-108. https://doi.org/10.1080/096708700227453

3. Andrei A-Ş, Salcher MM, Mehrshad M, Rychtecký P, Znachor P, Ghai R (2019) Niche-directed evolution modulates genome architecture in freshwater Planctomycetes. ISME J 13:1056-1071. https://doi.org/10.1038/s41396-018-0332-5

4. Barns SM, Cain EC, Sommerville L, Kuske CR (2007) Acidobacteria phylum sequences in uranium-contaminated subsurface sediments greatly expand the known diversity within the phylum. Applied Environmental Microbiology 73:3113-3116. https://doi.org/10.1128/AEM.02012-06

5. Bayer K, Jahn MT, Slaby BM, Moitinho-Silva L, Hentschel U (2018) Marine sponges as Chloroflexi hot spots: genomic insights and high-resolution visualization of an abundant and diverse symbiotic clade. mSystems 3.

https://doi.org/10.1128/mSystems.00150-18 
6. Bolyen E, Rideout JR, Dillon MR, Bokulich NA, Abnet CC, Al-Ghalith GA, Alexander H, Alm EJ, Arumugam M, Asnicar F, Bai Y, Bisanz JE, Bittinger K, Brejnrod A, Brislawn CJ, Brown CT, Callahan BJ, Caraballo-Rodríguez AM, Chase J, Cope EK, Da Silva R, Diener C, Dorrestein PC, Douglas GM, Durall DM, Duvallet C, Edwardson CF, Ernst M, Estaki M, Fouquier J, Gauglitz JM, Gibbons SM, Gibson DL, Gonzalez A, Gorlick K, Guo J, Hillmann B, Holmes S, Holste H, Huttenhower C, Huttley GA, Janssen S, Jarmusch AK, Jiang L, Kaehler BD, Kang KB, Keefe CR, Keim P, Kelley ST, Knights D, Koester I, Kosciolek T, Kreps J, Langille MGI, Lee J, Ley R, Liu Y-X, Loftfield E, Lozupone C, Maher M, Marotz C, Martin BD, McDonald D, Mclver LJ, Melnik AV, Metcalf JL, Morgan SC, Morton JT, Naimey AT, Navas-Molina JA, Nothias LF, Orchanian SB, Pearson T, Peoples SL, Petras D, Preuss ML, Pruesse E, Rasmussen LB, Rivers A, Robeson MS, Rosenthal P, Segata N, Shaffer M, Shiffer A, Sinha R, Song SJ, Spear JR, Swafford AD, Thompson LR, Torres PJ, Trinh P, Tripathi A, Turnbaugh PJ, UI-Hasan S, van der Hooft JJJ, Vargas F, Vázquez-Baeza Y, Vogtmann E, von Hippel M, Walters W, Wan Y, Wang M, Warren J, Weber KC, Williamson, C.H.D., Willis, AD, Xu ZZ, Zaneveld JR, Zhang Y, Zhu, Q., Knight, R., Caporaso, J.G., 2019. Reproducible, interactive, scalable and extensible microbiome data science using QIIME 2. Nature Biotechnology 37, 852-857. https://doi.org/10.1038/s41587-019-0209-9

7. Bossio DA, Girvan MS, Verchot L, Bullimore J, Borelli T, Albrecht A, Scow KM, Ball AS, Pretty JN, Osborn AM (2005) Soil microbial community response to land use change in an agricultural landscape of western Kenya. Microb Ecol 49:50-62. https://doi.org/10.1007/s00248-003-0209-6

8. Brochier-Armanet C, Gribaldo S, Forterre P (2012) Spotlight on the Thaumarchaeota. The ISME Journal 6:227-230. https://doi.org/10.1038/ismej.2011.145

9. Bünger W, Jiang X, Müller J, Hurek T, Reinhold-Hurek B (2020) Novel cultivated endophytic Verrucomicrobia reveal deep-rooting traits of bacteria to associate with plants. Sci Rep 10:8692. https://doi.org/10.1038/s41598-020-65277-6

10. Cadisch G, Sylvester-Bradley R, Boller BC, Nösberger J (1993) Effects of phosphorus and potassium on N2 fixation (15Ndilution) of field-grown Centrosema acutifolium and C. macrocarpum. Field Crops Research 31:329-340. https://doi.org/10.1016/0378-4290(93)90071-T

11. Cardarelli EL, Bargar JR, Francis CA (2020) Diverse Thaumarchaeota dominate subsurface ammonia-oxidizing communities in semi-arid floodplains in the western United States. Microb Ecol 80:778-792. https://doi.org/10.1007/s00248-020-01534-5

12. Chaparro JM, Sheflin AM, Manter DK, Vivanco JM (2012) Manipulating the soil microbiome to increase soil health and plant fertility. Biology Fertility Soils 48:489-499. https://doi.org/10.1007/s00374-012-0691-4

13. Chen C, Zhang J, Lu M, Qin C, Chen Y, Yang L, Huang Q, Wang J, Shen Z, Shen Q (2016) Microbial communities of an arable soil treated for 8 years with organic and inorganic fertilizers. Biol Fertil Soils 52:455-467. https://doi.org/10.1007/s00374-0161089-5

14. Chen Q-L, Ding J, Zhu D, Hu H-W, Delgado-Baquerizo M, Ma Y-B, He J-Z, Zhu Y-G (2020) Rare microbial taxa as the major drivers of ecosystem multifunctionality in long-term fertilized soils. Soil Biol Biochem 141:107686. https://doi.org/10.1016/j.soilbio.2019.107686

15. Collins M, Lang DJ, Kelling KA (1986) Effects of phosphorus, potassium, and sulfur on alfalfa nitrogen-fixation under field conditions. Agron J 78:959-963. https://doi.org/10.2134/agronj1986.00021962007800060005x

16. Correia MV, Pereira LCR, De Almeida L, Williams RL, Freach J, Nesbitt H, Erskine W (2014) Maize-mucuna (Mucuna pruriens (L.) DC) relay intercropping in the lowland tropics of Timor-Leste. Field Crops Research 156:272-280. https://doi.org/10.1016/j.fcr.2013.10.011

17. de Chaves MG, Silva GGZ, Rossetto R, Edwards RA, Tsai SM, Navarrete AA (2019) Acidobacteria subgroups and their metabolic potential for carbon degradation in sugarcane soil amended with vinasse and nitrogen fertilizers. Front Microbiol 10. https://doi.org/10.3389/fmicb.2019.01680

18. Díaz S, Fargione J, lii FSC, Tilman D (2006) Biodiversity loss threatens human well-being. PLOS Biology 4:e277. https://doi.org/10.1371/journal.pbio.0040277

19. Duchene O, Vian J-F, Celette F (2017) Intercropping with legume for agroecological cropping systems: Complementarity and facilitation processes and the importance of soil microorganisms. A review. Agr Ecosyst Environ 240:148-161. https://doi.org/10.1016/j.agee.2017.02.019

20. Dunfield PF, Yuryev A, Senin P, Smirnova AV, Stott MB, Hou S, Ly B, Saw JH, Zhou Z, Ren Y, Wang J, Mountain BW, Crowe MA, Weatherby TM, Bodelier PLE, Liesack W, Feng L, Wang L, Alam M (2007) Methane oxidation by an extremely acidophilic bacterium of the phylum Verrucomicrobia. Nature 450:879-882. https://doi.org/10.1038/nature06411

Page 9/18 
21. Francioli D, Schulz E, Lentendu G, Wubet T, Buscot F, Reitz T (2016) Mineral vs. organic amendments: microbial community structure, activity and abundance of agriculturally relevant microbes are driven by long-term fertilization strategies. Front Microbiol 7. https://doi.org/10.3389/fmicb.2016.01446

22. Fu Z, Zhou L, Chen P, Du Q, Pang T, Song C, Wang X, Liu W, Yang W, Yong T (2019) Effects of maize-soybean relay intercropping on crop nutrient uptake and soil bacterial community. Journal of Integrative Agriculture 18:2006-2018. https://doi.org/10.1016/S2095-3119(18)62114-8

23. Fuerst JA, Sagulenko E (2011) Beyond the bacterium: planctomycetes challenge our concepts of microbial structure and function. Nat Rev Microbiol 9:403-413. https://doi.org/10.1038/nrmicro2578

24. Gao Y, Zhou P, Mao L, Zhi Y, Zhang C, Shi W (2010) Effects of plant species coexistence on soil enzyme activities and soil microbial community structure under $\mathrm{Cd}$ and $\mathrm{Pb}$ combined pollution. J Environ Sci 22:1040-1048. https://doi.org/10.1016/S1001-0742(09)60215-1

25. Ghosh PK, Tripathi AK, Bandyopadhyay KK, Manna MC (2009) Assessment of nutrient competition and nutrient requirement in soybean/sorghum intercropping system. Eur J Agron 31:43-50. https://doi.org/10.1016/j.eja.2009.03.002

26. Gong W, Yan X, Wang J, Hu T, Gong Y (2009) Long-term manure and fertilizer effects on soil organic matter fractions and microbes under a wheat-maize cropping system in northern China. Geoderma 149:318-324.

https://doi.org/10.1016/j.geoderma.2008.12.010

27. Granzow S, Kaiser K, Wemheuer B, Pfeiffer B, Daniel R, Vidal S, Wemheuer F (2017) The effects of cropping regimes on fungal and bacterial communities of wheat and faba bean in a greenhouse pot experiment differ between plant species and compartment. Front Microbiol 8. https://doi.org/10.3389/fmicb.2017.00902

28. Gul S, Whalen JK, Thomas BW, Sachdeva V, Deng H (2015) Physico-chemical properties and microbial responses in biocharamended soils: Mechanisms and future directions. Agr Ecosyst Environ 206:46-59.

https://doi.org/10.1016/j.agee.2015.03.015

29. Harter J, Krause H-M, Schuettler S, Ruser R, Fromme M, Scholten T, Kappler A, Behrens S (2014) Linking $\mathrm{N}_{2} \mathrm{O}$ emissions from biochar-amended soil to the structure and function of the N-cycling microbial community. ISME J 8:660-674. https://doi.org/10.1038/ismej.2013.160

30. He J-Z, Zheng Y, Chen C-R, He Y-Q, Zhang L-M (2008) Microbial composition and diversity of an upland red soil under long-term fertilization treatments as revealed by culture-dependent and culture-independent approaches. J Soils Sediments 8:349-358. https://doi.org/10.1007/s11368-008-0025-1

31. He S, Stevens SLR, Chan L-K, Bertilsson S, Rio TG, del, Tringe SG, Malmstrom RR, McMahon KD (2017) Ecophysiology of freshwater Verrucomicrobia inferred from metagenome-assembled genomes. mSphere 2. https://doi.org/10.1128/mSphere.00277-17

32. He X, Yin H, Fang C, Xiong J, Han L, Yang Z, Huang G (2021) Metagenomic and q-PCR analysis reveals the effect of powder bamboo biochar on nitrous oxide and ammonia emissions during aerobic composting. Biores Technol 323:124567. https://doi.org/10.1016/j.biortech.2020.124567

33. Herlemann DPR, Lundin D, Labrenz M, Jürgens K, Zheng Z, Aspeborg H, Andersson AF (2013) Metagenomic de novo assembly of an aquatic representative of the Verrucomicrobial class spartobacteria. mBio 4. https://doi.org/10.1128/mBio.00569-12

34. Hol WHG, Boer WD, Termorshuizen AJ, Meyer KM, Schneider JHM, Dam NMV, Veen JAV, Putten WHVD (2010) Reduction of rare soil microbes modifies plant-herbivore interactions. Ecol Lett 13:292-301. https://doi.org/10.1111/j.1461-0248.2009.01424.x

35. Horner A, Browett SS, Antwis RE (2019) Mixed-cropping between field pea varieties alters root bacterial and fungal communities. Sci Rep 9:16953. https://doi.org/10.1038/s41598-019-53342-8

36. Isaac ME, Hinsinger P, Harmand JM (2012) Nitrogen and phosphorus economy of a legume tree-cereal intercropping system under controlled conditions. Science of The Total Environment 434:71-78. https://doi.org/10.1016/j.scitotenv.2011.12.071

37. Jousset A, Bienhold C, Chatzinotas A, Gallien L, Gobet A, Kurm V, Küsel K, Rillig MC, Rivett DW, Salles JF, van der Heijden MGA, Youssef NH, Zhang X, Wei Z, Hol WHG (2017) Where less may be more: how the rare biosphere pulls ecosystems strings. The ISME Journal 11:853-862. https://doi.org/10.1038/ismej.2016.174

38. Kanehisa M, Goto S (2000) KEGG: Kyoto Encyclopedia of Genes and Genomes. Nucleic Acids Res 28:27-30. https://doi.org/10.1093/nar/28.1.27

Page 10/18 
39. Kehoe L, Romero-Muñoz A, Polaina E, Estes L, Kreft H, Kuemmerle T (2017) Biodiversity at risk under future cropland expansion and intensification. Nature Ecology Evolution 1:1129-1135. https://doi.org/10.1038/s41559-017-0234-3

40. Kielak AM, Barreto CC, Kowalchuk GA, van Veen JA, Kuramae EE (2016) The ecology of Acidobacteria: Moving beyond genes and genomes. Frontiers Microbiology 7. https://doi.org/10.3389/fmicb.2016.00744

41. Kihara J, Martius C, Bationo A, Thuita M, Lesueur D, Herrmann L, Amelung W, Vlek PLG (2012) Soil aggregation and total diversity of bacteria and fungi in various tillage systems of sub-humid and semi-arid Kenya. Appl Soil Ecol 58:12-20. https://doi.org/10.1016/j.apsoil.2012.03.004

42. Kurm V, Putten WH van der, Boer W de, Naus-Wiezer S, Hol WHG (2017) Low abundant soil bacteria can be metabolically versatile and fast growing. Ecology 98:555-564. https://doi.org/10.1002/ecy.1670

43. Lee S-H, Ka J-O, Cho J-C (2008) Members of the phylum Acidobacteria are dominant and metabolically active in rhizosphere soil. FEMS Microbiol Lett 285:263-269. https://doi.org/10.1111/j.1574-6968.2008.01232.x

44. Lenth R, Singmann H, Love J, Buerkner P, Herve M (2020) emmeans: Estimated Marginal Means, aka Least-Squares Means. https://CRAN.R-project.org/package=emmeans

45. Li C-J, Li Y-Y, Yu C-B, Sun J-H, Christie P, An M, Zhang F-S, Li L (2011) Crop nitrogen use and soil mineral nitrogen accumulation under different crop combinations and patterns of strip intercropping in northwest China. Plant Soil 342:221-231. https://doi.org/10.1007/s11104-010-0686-6

46. Li H, Shen J, Zhang F, Marschner P, Cawthray G, Rengel Z (2010) Phosphorus uptake and rhizosphere properties of intercropped and monocropped maize, faba bean, and white lupin in acidic soil. Biol Fertil Soils 46:79-91. https://doi.org/10.1007/s00374009-0411-x

47. Li X, Mu Y, Cheng Y, Liu X, Nian H (2013) Effects of intercropping sugarcane and soybean on growth, rhizosphere soil microbes, nitrogen and phosphorus availability. Acta Physiologiae Plantarum 7

48. Lian T, Mu Y, Jin J, Ma Q, Cheng Y, Cai Z, Nian H (2019) Impact of intercropping on the coupling between soil microbial community structure, activity, and nutrient-use efficiencies. PeerJ 7:e6412. https://doi.org/10.7717/peerj.6412

49. Liao H, Li Y, Yao H (2019) Biochar amendment stimulates utilization of plant-derived carbon by soil bacteria in an intercropping System. Frontiers Microbiology 10. https://doi.org/10.3389/fmicb.2019.01361

50. Liu L, Wang Y, Yan X, Li J, Jiao N, Hu S (2017) Biochar amendments increase the yield advantage of legume-based intercropping systems over monoculture. Agr Ecosyst Environ 237:16-23. https://doi.org/10.1016/j.agee.2016.12.026

51. Loreau M, Naeem S, Inchausti P, Bengtsson J, Grime JP, Hector A, Hooper DU, Huston MA, Raffaelli D, Schmid B, Tilman D, Wardle DA (2001) Biodiversity and ecosystem functioning: Current knowledge and future challenges. Science 294:804-808. https://doi.org/10.1126/science.1064088

52. Marschner P, Crowley D, Yang CH (2004) Development of specific rhizosphere bacterial communities in relation to plant species, nutrition and soil type. Plant Soil 261:199-208. https://doi.org/10.1023/B:PLS0.0000035569.80747.c5

53. Martinez-Garcia M, Brazel DM, Swan BK, Arnosti C, Chain PSG, Reitenga KG, Xie G, Poulton NJ, Gomez ML, Masland DED, Thompson B, Bellows WK, Ziervogel K, Lo C-C, Ahmed S, Gleasner CD, Detter CJ, Stepanauskas R (2012) Capturing Single cell genomes of active polysaccharide degraders: An unexpected contribution of Verrucomicrobia. PLOS ONE 7:e35314. https://doi.org/10.1371/journal.pone.0035314

54. Nannipieri P, Ascher J, Ceccherini MT, Landi L, Pietramellara G, Renella G (2003) Microbial diversity and soil functions. Eur J Soil Sci 54:655-670. https://doi.org/10.1046/j.1351-0754.2003.0556.x

55. Nielsen S, Minchin T, Kimber S, van Zwieten L, Gilbert J, Munroe P, Joseph S, Thomas T (2014) Comparative analysis of the microbial communities in agricultural soil amended with enhanced biochars or traditional fertilisers. Agr Ecosyst Environ 191:73-82. https://doi.org/10.1016/j.agee.2014.04.006

56. Pester M, Schleper C, Wagner M (2011) The Thaumarchaeota: an emerging view of their phylogeny and ecophysiology. Curr Opin Microbiol 14:300-306. https://doi.org/10.1016/j.mib.2011.04.007

57. Pold G, Conlon EM, Huntemann M, Pillay M, Mikhailova N, Stamatis D, Reddy TBK, Daum C, Shapiro N, Kyrpides N, Woyke T, DeAngelis KM (2018) Genome sequence of Verrucomicrobium sp. strain GAS474, a novel bacterium isolated from soil. Genome Announcements 6. https://doi.org/10.1128/genomeA.01451-17

Page $11 / 18$ 
58. Rohr JR, Barrett CB, Civitello DJ, Craft ME, Delius B, DeLeo GA, Hudson PJ, Jouanard N, Nguyen KH, Ostfeld RS, Remais JV, Riveau G, Sokolow SH, Tilman D (2019) Emerging human infectious diseases and the links to global food production. Nature Sustainability 2:445-456. https://doi.org/10.1038/s41893-019-0293-3

59. Sanchez-Contreras M, Bauer WD, Gao M, Robinson JB, Allan Downie J (2007) Quorum-sensing regulation in rhizobia and its role in symbiotic interactions with legumes. Philosophical Transactions of the Royal Society B: Biological Sciences 362:11491163. https://doi.org/10.1098/rstb.2007.2041

60. Sangakkara UR, Hartwig UA, Nösberger J (1996) Soil moisture and potassium affect the performance of symbiotic nitrogen fixation in faba bean and common bean. Plant Soil 184:123-130. https://doi.org/10.1007/BF00029282

61. Shannon CE (1948) A mathematical theory of communication. The Bell system technical journal 27:379-423. http://dx.doi.org/10.1002/j.1538-7305.1948.tb01338.x

62. Simpson EH (1949) Measurement of Diversity. Nature 163:688-688. https://doi.org/10.1038/163688a0

63. Singh JS (2015) Microbes: The chief ecological engineers in reinstating equilibrium in degraded ecosystems. Agr Ecosyst Environ 203:80-82. https://doi.org/10.1016/j.agee.2015.01.026

64. Spang A, Hatzenpichler R, Brochier-Armanet C, Rattei T, Tischler P, Spieck E, Streit W, Stahl DA, Wagner M, Schleper C (2010) Distinct gene set in two different lineages of ammonia-oxidizing archaea supports the phylum Thaumarchaeota. Trends Microbiol 18:331-340. https://doi.org/10.1016/j.tim.2010.06.003

65. Sulieman S, Tran L-SP (2014) Symbiotic Nitrogen Fixation in Legume Nodules: Metabolism and Regulatory Mechanisms. Int J Mol Sci 15:19389-19393. https://doi.org/10.3390/ijms151119389

66. Wang J, Long Z, Min W, Hou Z (2020) Metagenomic analysis reveals the effects of cotton straw-derived biochar on soil nitrogen transformation in drip-irrigated cotton field. Environmental Science Polluttion Research 27:43929-43941. https://doi.org/10.1007/s11356-020-10267-4

67. Wemheuer F, Taylor JA, Daniel R, Johnston E, Meinicke P, Thomas T, Wemheuer B (2020) Tax4Fun2: prediction of habitatspecific functional profiles and functional redundancy based on 16S rRNA gene sequences. Environmental Microbiome 15:11. https://doi.org/10.1186/s40793-020-00358-7

68. Yamada T, Sekiguchi Y, Imachi H, Kamagata Y, Ohashi A, Harada H (2005) Diversity, Localization, and Physiological Properties of Filamentous Microbes Belonging to Chloroflexi Subphylum I in Mesophilic and Thermophilic Methanogenic Sludge Granules. Appl Environ Microbiol 71:7493-7503. https://doi.org/10.1128/AEM.71.11.7493-7503.2005

69. Yu, Lu, Homyak PM, Kang X, Brookes PC, Ye Y, Lin Y, Muhammad A, Xu J (2020) Changes in abundance and composition of nitrifying communities in barley (Hordeum vulgare L.) rhizosphere and bulk soils over the growth period following combined biochar and urea amendment. Biol Fertil Soils 56:169-183. https://doi.org/10.1007/s00374-019-01410-6

70. Yu L, Luo S, Xu X, Gou Y, Wang J (2020) The soil carbon cycle determined by GeoChip 5.0 in sugarcane and soybean intercropping systems with reduced nitrogen input in South China. Appl Soil Ecol 155:103653. https://doi.org/10.1016/j.apsoil.2020.103653

71. Yu L, Tang Y, Wang Z, Gou Y, Wang J (2019) Nitrogen-cycling genes and rhizosphere microbial community with reduced nitrogen application in maize/soybean strip intercropping. Nutrient Cycling in Agroecosystem 113:35-49. https://doi.org/10.1007/s10705-018-9960-4

72. Zabel F, Delzeit R, Schneider JM, Seppelt R, Mauser W, Václavík T (2019) Global impacts of future cropland expansion and intensification on agricultural markets and biodiversity. Nat Commun 10:2844. https://doi.org/10.1038/s41467-019-10775-z

73. Zhalnina K, Louie KB, Hao Z, Mansoori N, da Rocha UN, Shi S, Cho H, Karaoz U, Loqué D, Bowen BP, Firestone MK, Northen TR, Brodie EL (2018) Dynamic root exudate chemistry and microbial substrate preferences drive patterns in rhizosphere microbial community assembly. Nature Microbiology 3:470-480. https://doi.org/10.1038/s41564-018-0129-3

74. Zhang NN, Sun YM, Li L, Wang ET, Chen WX, Yuan HL (2010) Effects of intercropping and Rhizobium inoculation on yield and rhizosphere bacterial community of faba bean (Vicia faba L.). Biol Fertil Soils 46:625-639. https://doi.org/10.1007/s00374010-0469-5

75. Zhang Q, Acuña JJ, Inostroza NG, Mora ML, Radic S, Sadowsky MJ, Jorquera MA (2019) Endophytic bacterial communities associated with roots and leaves of plants growing in chilean extreme environments. Sci Rep 9:4950. https://doi.org/10.1038/s41598-019-41160-x

Page $12 / 18$ 


\section{Tables}

Table 1. Chemical properties of soil and carbonised chicken manure (CM). The number of replications was 3 for each property measurement.

\begin{tabular}{lll} 
Chemical properties & Soil & $\mathrm{CM}$ \\
\hline Water content $(\%)$ & $19.5 \pm 0.1$ & $19.1 \pm 1.2$ \\
\hline $\mathrm{C} / \mathrm{N}$ & $14.7 \pm 0.2$ & $10.0 \pm 0.4$ \\
\hline $\mathrm{pH}(1: 10)$ & $6.3 \pm 0.0$ & $10.4 \pm 0.3$ \\
\hline $\mathrm{EC}(\mu \mathrm{s} / \mathrm{cm})$ & $78.5 \pm 3.5$ & $12740 \pm 793$ \\
\hline $\mathrm{TN}(\%)$ & $0.25 \pm 0.01$ & $4.06 \pm 0.45$ \\
\hline $\mathrm{TC}(\%)$ & - & $40.5 \pm 3.4$ \\
\hline $\mathrm{P} \mathrm{g} \mathrm{kg}{ }^{-1}$ soil & $0.21 \pm 0.01$ & $36.8 \pm 1.0$ \\
\hline $\mathrm{Ca} \mathrm{g} \mathrm{kg}{ }^{-1}$ soil & $5.9 \pm 0.3$ & $134 \pm 5$ \\
\hline $\mathrm{Mg} \mathrm{g} \mathrm{kg}^{-1}$ soil & $0.53 \pm 0.01$ & $15.1 \pm 0.3$ \\
\hline $\mathrm{K} \mathrm{g} \mathrm{kg}^{-1}$ soil & $0.56 \pm 0.01$ & $45.3 \pm 0.9$
\end{tabular}

Table 2. Soil pH, nitrate and ammonium content after plant cultivation. The expressed plant species included single maize, SM; maize cropped with velvet bean [Mucuna pruriens (L.) DC.], MM; maize cropped with common bean (Phaseolus vulgaris L.), PM; maize cropped with cowpea [Vigna unguiculate (L.) Walp.], VM. Fertilisation was undertaken for the control, Ctr; chemical fertiliser, $\mathrm{CF}$; and carbonised chicken manure, $\mathrm{CM}$. Two-way ANOVA was performed to examine the effects of the interactions between plant species and fertiliser treatments. $p$-values are shown at the bottom of the table. 


\begin{tabular}{|c|c|c|c|}
\hline Treatment & $\mathrm{pH}\left(\mathrm{H}_{2} \mathrm{O}\right)$ & $\mathrm{NO}_{3}{ }^{-}-\mathrm{N}\left(\mathrm{mg} \mathrm{kg}^{-1}\right)$ & $\mathrm{NH}_{4}^{+}-\mathrm{N}\left(\mathrm{mg} \mathrm{kg}^{-1}\right)$ \\
\hline \multicolumn{4}{|l|}{ SM } \\
\hline Ctr & $6.7 \pm 0.03$ & $8.2 \pm 1.6$ & $4.7 \pm 0.30$ \\
\hline $\mathrm{CF}$ & $6.7 \pm 0.04$ & $7.1 \pm 0.4$ & $3.4 \pm 0.75$ \\
\hline $\mathrm{CM}$ & $7.6 \pm 0.09$ & $15.9 \pm 2.4$ & $5.4 \pm 1.22$ \\
\hline \multicolumn{4}{|l|}{ MM } \\
\hline Ctr & $6.7 \pm 0.02$ & $10.9 \pm 4.2$ & $4.2 \pm 2.64$ \\
\hline $\mathrm{CF}$ & $6.7 \pm 0.02$ & $6.3 \pm 3.3$ & $4.7 \pm 1.37$ \\
\hline $\mathrm{CM}$ & $7.3 \pm 0.10$ & $19.7 \pm 6.2$ & $5.1 \pm 2.48$ \\
\hline \multicolumn{4}{|l|}{ PM } \\
\hline Ctr & $6.7 \pm 0.02$ & $12.8 \pm 2.2$ & $6.0 \pm 2.80$ \\
\hline $\mathrm{CF}$ & $6.6 \pm 0.02$ & $7.9 \pm 3.2$ & $5.7 \pm 0.98$ \\
\hline $\mathrm{CM}$ & $7.2 \pm 0.12$ & $35.0 \pm 19.3$ & $2.6 \pm 0.37$ \\
\hline \multicolumn{4}{|l|}{ VM } \\
\hline Ctr & $6.7 \pm 0.02$ & $10.6 \pm 3.2$ & $4.5 \pm 1.35$ \\
\hline $\mathrm{CF}$ & $6.7 \pm 0.03$ & $6.7 \pm 3.1$ & $4.9 \pm 0.68$ \\
\hline $\mathrm{CM}$ & $7.2 \pm 0.08$ & $30.8 \pm 13.2$ & $5.4 \pm 2.22$ \\
\hline Two-way ANOVA & $p$ & & \\
\hline Plant & $<0.001$ & 0.45 & 0.92 \\
\hline Fertiliser & $<0.001$ & $<0.001$ & 0.90 \\
\hline Plant $\times$ fertiliser & $<0.01$ & 0.91 & 0.39 \\
\hline
\end{tabular}

Table 3. Bacteria phyla with permutational $p<0.001$ (permutation $=9999)$. Two-way ANOVA with plant species and fertiliser treatments as the factors was performed. $p$-values are shown in the table. 


\begin{tabular}{llll} 
Phylum & \multicolumn{3}{l}{ Two-way ANOVA } \\
\cline { 2 - 4 } & Fertiliser & Plant & Plant $\times$ fertiliser \\
\hline Thaumarchaeota & 0.018 & 0.19 & $<0.01$ \\
\hline Acidobacteria & $<0.001$ & $<0.01$ & 0.063 \\
\hline Actinobacteria & 0.35 & $<0.01$ & 0.074 \\
\hline Armatimonadetes & $<0.001$ & 0.0021 & $<0.01$ \\
\hline Bacteroidetes & 0.097 & 0.5 & 0.12 \\
\hline Chloroflexi & $<0.001$ & $<0.001$ & $<0.001$ \\
\hline Gemmatimonadetes & 0.48 & 0.51 & 0.048 \\
\hline Latescibacteria & 0.34 & 0.18 & 0.48 \\
\hline Nitrospirae & $<0.001$ & $<0.001$ & 0.47 \\
\hline Planctomycetes & $<0.001$ & 0.096 & $<0.001$ \\
\hline Proteobacteria & $<0.001$ & 0.16 & $<0.01$ \\
\hline Verrucomicrobia & $<0.001$ & $<0.001$ & $<0.001$
\end{tabular}

Table 4. Relative abundance of the phyla showed a significant interaction between plant species and fertiliser treatments. The results from multiple pairwise comparisons are shown as different letters, indicating significant differences between treatments $(p<$ 0.05).

Treatment Relative abundance (\%)

Thaumarchaeota Armatimonadetes Chloroflexi Planctomycetes Verrucomicrobia Proteobacteria

\begin{tabular}{|c|c|c|c|c|c|c|}
\hline \multicolumn{7}{|l|}{ Ctr } \\
\hline SM & $3.23^{\mathrm{a}}$ & $0.58^{a}$ & $7.84^{\mathrm{ab}}$ & $6.76^{a}$ & $2.93^{\mathrm{a}}$ & $29.93^{b}$ \\
\hline MM & $4.70^{\mathrm{ab}}$ & $0.46^{\mathrm{a}}$ & $7.58^{\mathrm{a}}$ & $8.53^{b}$ & $4.37^{b}$ & $28.19^{a b}$ \\
\hline PM & $5.22^{\mathrm{ab}}$ & $0.42^{\mathrm{a}}$ & $7.84^{\mathrm{ab}}$ & $8.21^{\mathrm{ab}}$ & $4.20^{\mathrm{b}}$ & $27.92^{\mathrm{ab}}$ \\
\hline VM & $5.66^{b}$ & $0.53^{a}$ & $8.74^{\mathrm{b}}$ & $10.74^{\mathrm{C}}$ & $4.57^{b}$ & $25.13^{a}$ \\
\hline \multicolumn{7}{|l|}{$\mathrm{CF}$} \\
\hline SM & $4.94^{\mathrm{a}}$ & $0.62^{\mathrm{a}}$ & $8.76^{\mathrm{b}}$ & $9.75^{b}$ & $4.08^{a}$ & $26.95^{a}$ \\
\hline MM & $4.21^{\mathrm{a}}$ & $0.60^{a}$ & $8.03^{\mathrm{ab}}$ & $8.48^{\mathrm{ab}}$ & $4.43^{\mathrm{a}}$ & $26.49^{a}$ \\
\hline PM & $4.72^{\mathrm{a}}$ & $0.57^{a}$ & $7.95^{\mathrm{ab}}$ & $8.70^{\mathrm{ab}}$ & $3.93^{a}$ & $27.05^{a}$ \\
\hline VM & $4.23^{a}$ & $0.53^{a}$ & $7.71^{\mathrm{a}}$ & $7.63^{a}$ & $3.78^{a}$ & $28.31^{a}$ \\
\hline \multicolumn{7}{|l|}{$\mathrm{CM}$} \\
\hline SM & $5.50^{\mathrm{ab}}$ & $0.83^{b}$ & $12.10^{c}$ & $10.94^{\mathrm{b}}$ & $5.89^{b}$ & $22.79^{a b}$ \\
\hline MM & $6.67^{b}$ & $0.72^{b}$ & $12.27^{\mathrm{c}}$ & $11.19^{b}$ & $6.19^{b}$ & $20.04^{\mathrm{a}}$ \\
\hline PM & $4.01^{a}$ & $0.76^{b}$ & $10.65^{b}$ & $9.09^{a}$ & $4.56^{\mathrm{a}}$ & $24.21^{b}$ \\
\hline VM & $6.19^{b}$ & $0.48^{a}$ & $8.70^{\mathrm{a}}$ & $7.94^{\mathrm{a}}$ & $4.50^{\mathrm{a}}$ & $25.14^{b}$ \\
\hline
\end{tabular}




\section{Figures}

(a)

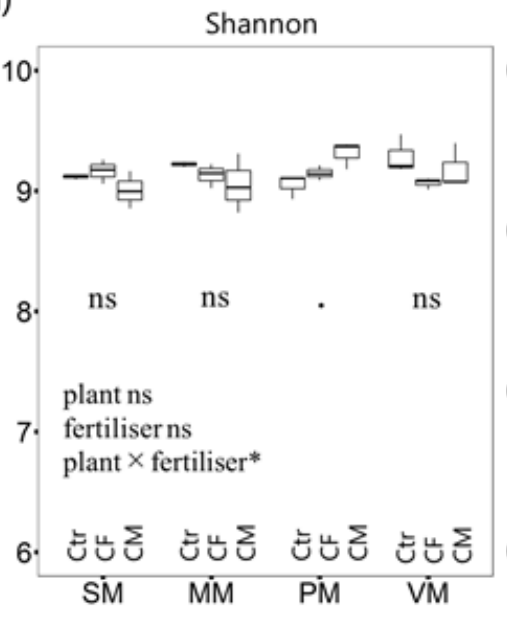

(b)

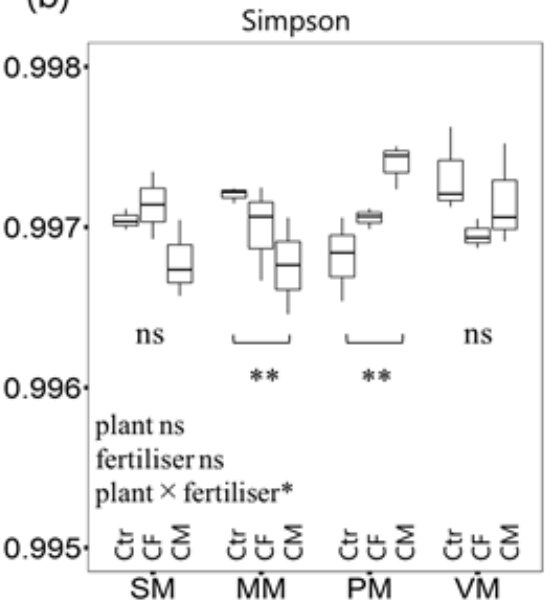

\section{Figure 1}

Box-plot analysis of bacterial OTU a-diversity indicating (a) Shannon's index and (b) Simpson's index. Two-way ANOVA and TukeyKramer's pairwise comparison were performed on calculated a-diversity indices: $\cdot p<0.25 ;{ }^{*} p<0.05 ;{ }^{* \star} p<0.01$. The abbreviations of plant species were as follows: single maize, SM; maize cropped with velvet bean, MM; maize cropped with common bean, MP; maize cropped with cowpea, VM. Fertiliser treatments were abbreviated as no fertiliser, Ctr; chemical fertiliser, CF; and carbonised chicken manure, CM.

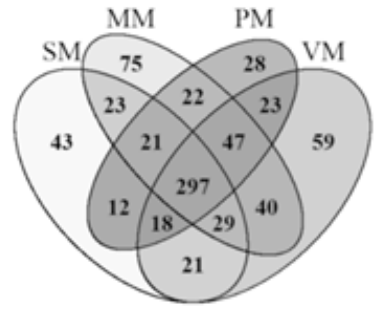

Ctr

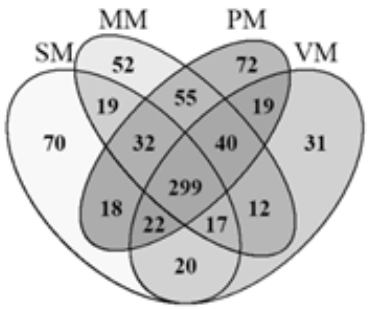

CF

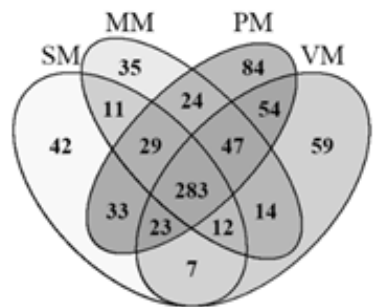

CM

\section{Figure 2}

Distribution of OTUs among different mixed cropping systems within fertiliser treatments. The numbers show the shared and unique OTUs in each treatment. Overlapping circles show the shared OTUs among treatments. Each circle includes OTUs that cooccurred among three replications. 


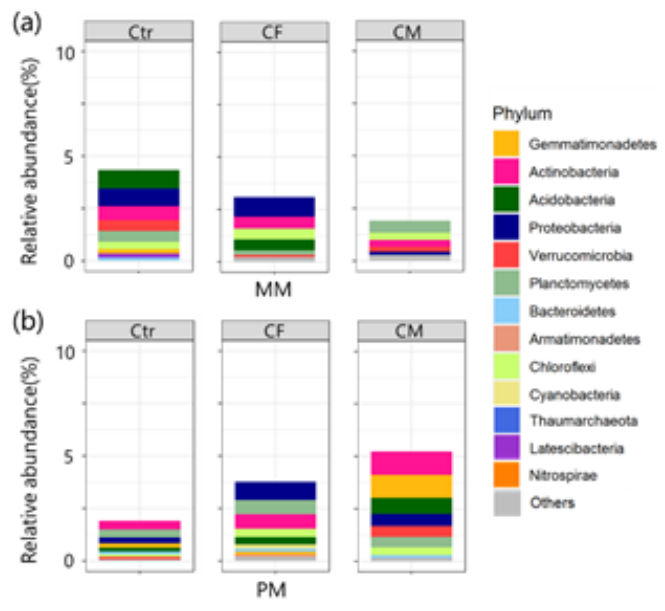

\section{Figure 3}

Relative abundance of unique OTU phyla found in MM (a) and PM (b) treatments. Bar plots indicate the total relative abundance dimension with the averaged value across replications. Only phyla with a relative abundance of $>0.1 \%$ in the averaged value are represented.
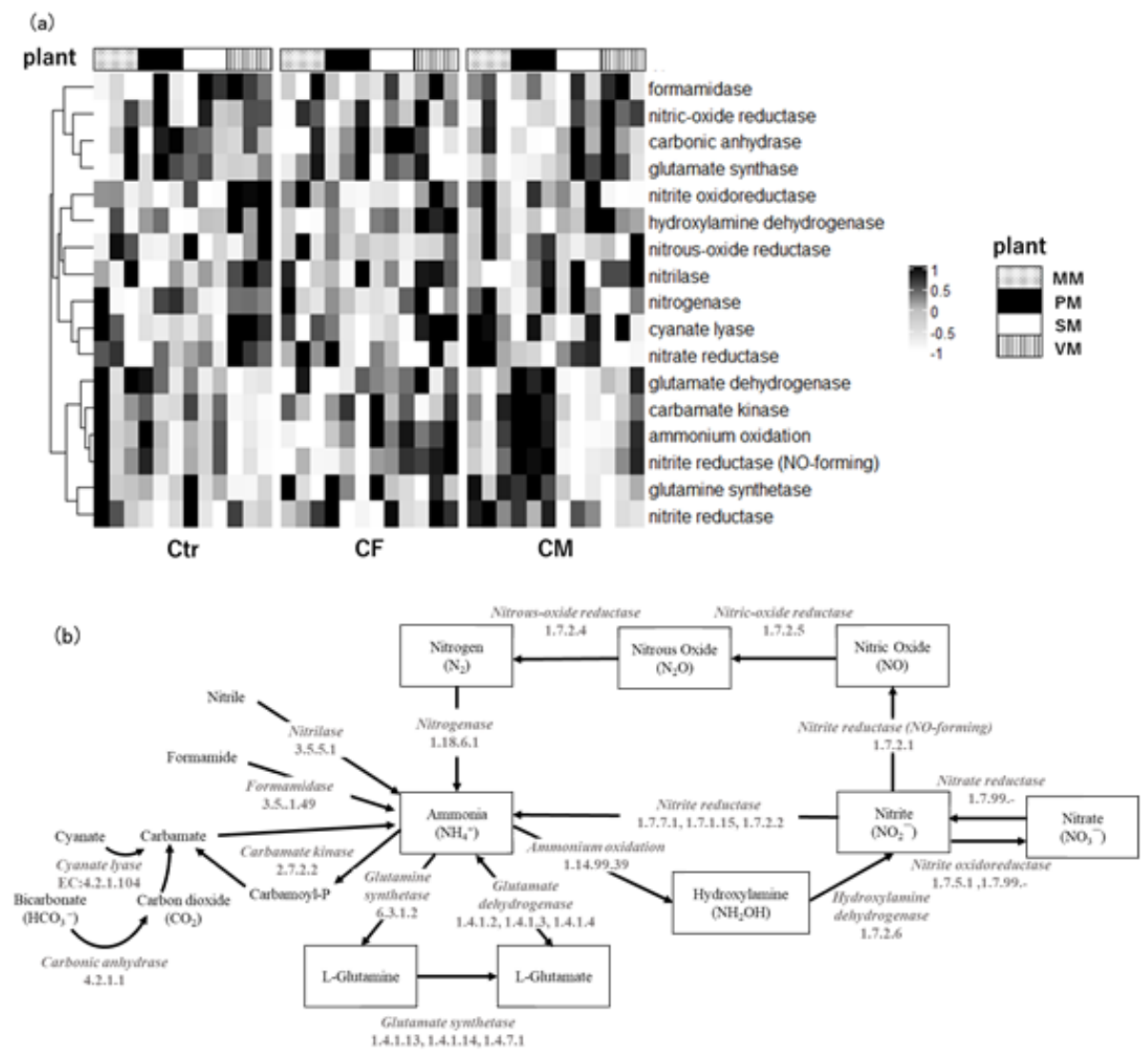

\section{Figure 4}

(a) Predicted bacterial genes coding the $\mathrm{N}$ metabolism pathway based on the KEGG database $\left({ }^{\star} \mathrm{p}<0.05\right.$; ${ }^{\star \star} \mathrm{p}<0.01$; $\left.{ }^{\star \star \star} \mathrm{p}<0.001\right)$. Individual KEGG codes are ammonium oxidation [EC: 1.14.99.39], carbamate kinase [EC: 2.7.2.2], carbonic anhydrase [EC: 4.2.1.1], cyanate lyase [EC: 4.2.1.104], formamidase [EC: 3.5.1.49], glutamate dehydrogenase [EC: 1.4.1.2; EC: 1.4.1.3; EC: 1.4.1.4], glutamate synthase [EC:1.4.1.13 1.4.1.14, EC:1.4.7.1], glutamine synthetase [EC: 6.3.1.2], hydroxylamine dehydrogenase [EC: 1.7.2.6], nitrate reductase [EC: 1.7.99.-], nitric oxide reductase [EC: 1.7.2.5], nitrilase [EC: 3.5.5.1], nitrite oxidoreductase [EC: 1.7.5.1; EC: 1.7.99.-], 
nitrite reductase [EC: 1.7.7.1; 1.7.1.15; 1.7.2.2], nitrite reductase (NO-forming) [EC: 1.7.2.1], nitrogenase [EC: 1.18.6.1], and nitrous oxide reductase [EC: 1.7.2.4]. (b) N metabolism pathway (ko00910) and enzymes based on the KEGG database.

\section{Supplementary Files}

This is a list of supplementary files associated with this preprint. Click to download.

- Supplementary.docx 